\title{
Three-dimensional field perspective on deformation, flow, and growth of the lower continental crust (Dharwar craton, India)
}

\author{
Dominique Chardon ${ }^{1,2,3}$ and Mudlappa Jayananda ${ }^{4}$ \\ Received 8 February 2007; revised 11 October 2007; accepted 30 October 2007; published 22 February 2008.
}

[1] The study of fabric development and juvenile batholith emplacement across the tilted crustal section of the Eastern Dharwar craton shows that horizontal, constrictional deformation affected large volumes of the midcrust and lower crust at the time of regional partial melting and magmatic accretion. Constriction is achieved by a combination of coeval shallow and steep planar fabrics sharing a common horizontal elongation direction, two sets of conjugate strike-slip shears, and extensional shear zones. The Eastern Dharwar craton illustrates an end-member deformation mode by which a particularly weakened lithosphere responds to shortening by developing distributed, horizontal plane strain on a crustal scale, resulting from the combination of crustal shortening and lateral gravity-driven flow. Thinning accompanying constrictional deformation is interpreted as compensating for juvenile magmatic accretion and thickening of greenstone belts and as acting to maintain a stable crustal thickness. Such a midcrustal to lower crustal deformation process may provide a resolution of the batholithic room problem in a softened crust submitted to lateral shortening and may explain nearly isobaric retrograde pressuretemperature-time paths of high temperature-low pressure high-grade terrains. Citation: Chardon, D., and M. Jayananda (2008), Three-dimensional field perspective on deformation, flow, and growth of the lower continental crust (Dharwar craton, India), Tectonics, 27, TC1014, doi:10.1029/ 2007 TC002120.

\footnotetext{
${ }^{1}$ UMR 6635, CNRS, Centre Européen de Recherche et d'Enseignement de Géosciences de 1'Environnement, Aix-Marseille Universités, Aix-enProvence, France.

${ }^{2}$ UMR 161, IRD, Centre Européen de Recherche et d'Enseignement de Géosciences de l'Environnement, Nouméa, New Caledonia.

${ }^{3}$ Now at Laboratoire des Mécanismes et Transferts en Géologie, CNRS, IRD, Observatoire Midi-Pyrénées, Université Paul Sabatier, Toulouse, France.

${ }^{4}$ Department of Geology, Bangalore University, Bangalore, India.
}

Copyright 2008 by the American Geophysical Union. 0278-7407/08/2007TC002120

\section{Introduction}

[2] The structural, metamorphic and plutonic patterns of high-grade terrains do not fit thermomechanical models of Phanerozoic collisional orogens [Wells, 1981; Sandiford, 1989; Bohlen, 1991; Choukroune et al., 1995; Collins, 2002; Cagnard et al., 2006a]. More specifically, the common occurrence of homogenous strain patterns over very large areas of the midcrust and lower crust leads to the concept of hot and wide orogens developed in a weak lithosphere deforming pervasively, as opposed to rigid lithosphere deforming only along narrow linear belts [Choukroune et al., 1995; Cruden et al., 2006; Cagnard et al., 2006a, 2006b; Rey and Houseman, 2006]. Within the framework of weak lithosphere, the interplay of deformation and mass transfer accompanying juvenile magmatic accretion in the lower crust is key to the understanding of continental growth and differentiation.

[3] Several studies have addressed the pluton space problem in the midcrust and upper crust [e.g., Hutton, 1988; Tikoff et al., 1999] and the role of crustal-scale wrench zones in transferring fluids from the mantle to the midcrust or in controlling the collection and ascent of magmas and pluton emplacement [Newton, 1990a; de Saint Blanquat et al., 1998]. Little is known, however, about the role of macroscale to regional-scale deformation in establishing the boundary conditions and structural framework enabling large volumes of juvenile magma to intrude the lower crust. This point is crucial when addressing the question of the mechanical behavior of sites of crustal growth, especially Precambrian provinces (where most of the present continental masses have been extracted from the mantle) and modern magmatic arcs.

[4] The tectonic and mechanical significance of regional strain fabrics and their interference patterns in the exposed deep crust remains a matter of debate, and the subject of renewed interest [Watterson, 1968; Myers, 1976; Park, 1981; Sandiford, 1989; Shackleton, 1993; Dirks et al., 1997; Martelat et al., 2000; Williams and Jiang, 2005]. The interpretation of the widespread, pervasive shallow fabrics of high-grade terrains is a key issue; in particular, whether shallowly dipping fabrics in high-grade terrains record mountain building, their collapse, or are part of the flow providing space for magma emplacement.

[5] The present study has two main goals. First, it addresses the kinematic and mechanical significance of distributed tectonic fabrics in portions of deep continental crust. Second, it evaluates the interactions between regional fabric development and emplacement mode of juvenile 


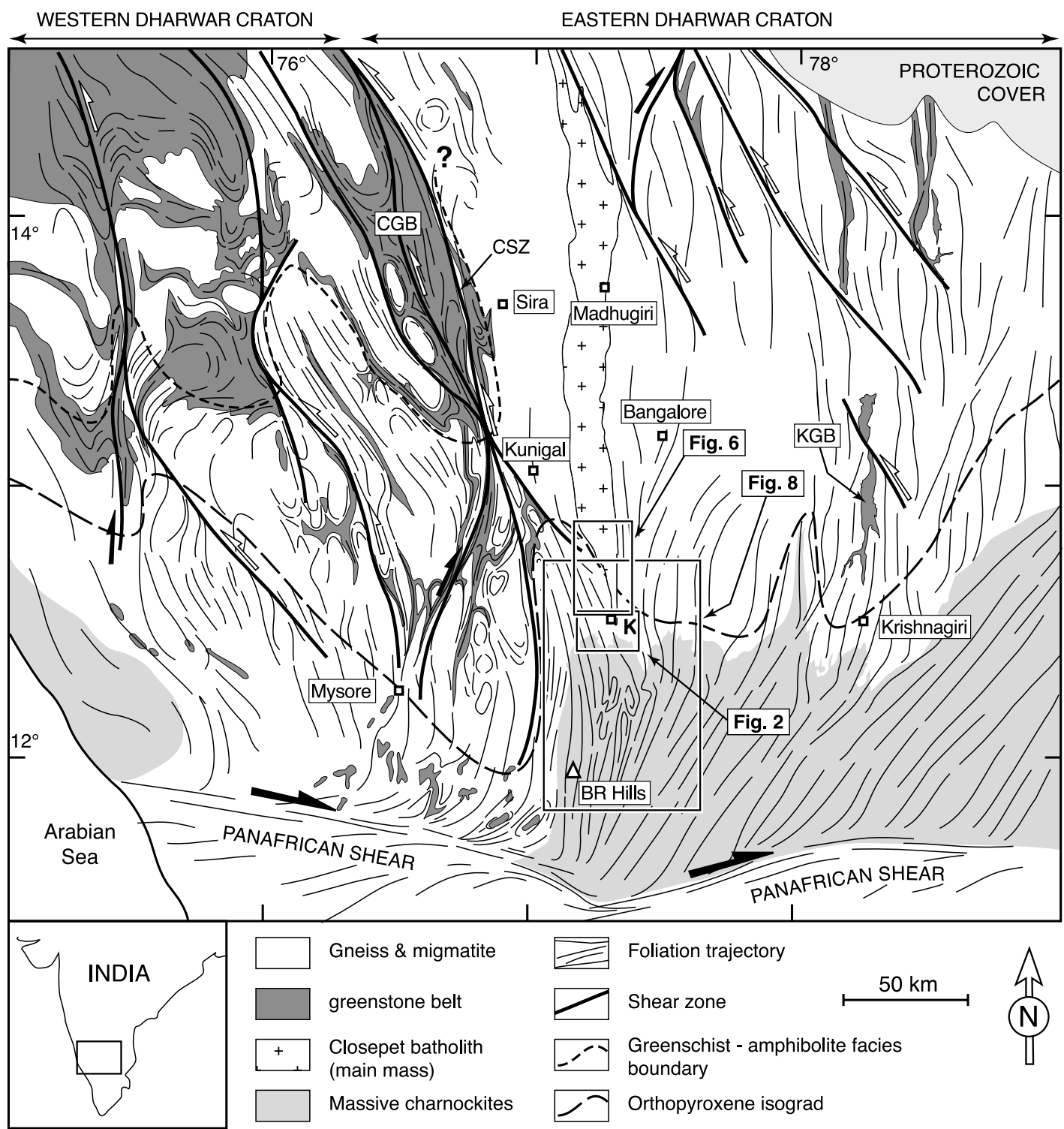

Figure 1. Structural map of the southern part of the Dharwar craton, modified after Bouhallier et al. [1995] for the Western Dharwar craton and based on reconnaissance geology and a compilation of foliation readings for the Eastern Dharwar craton. Boxes show locations for Figures 2, 6, and 8. CGB, Chitradurga greenstone belt; CSZ, Chitradurga shear zone; KGB, Kolar greenstone belt; K, Kabbaldurga.

felsic magmas in such portions of lower crust. The study is based on the structural analysis of the relations between regional penetrative deformation and emplacement of a juvenile batholith in the vicinity of the granulite isograd exposed in the world-class tilted crustal section of the Eastern Dharwar craton (India).

\section{Geological Background}

[6] The Dharwar craton is made of 3.4-2.7 Ga tonalitetrondhjemite-granodiorite (TTG) gneisses and 3.3-2.6 Ga greenstones [Chadwick et al., 2000; Jayananda et al., 2000]. The craton acquired its final structure between 2.56 and 2.51 Ga during a HT-LP tectonometamorphic episode, characterized by the development of a regional array of transcurrent shear zones [Drury et al., 1984; Peucat et al., 1993; Bouhallier, 1995; Jayananda et al., 2000; Chadwick et al., 2000; Chardon et al., 2002] (Figure 1). This tectonic episode accompanied massive felsic juvenile magmatic accretion in the Eastern Dharwar craton [Peucat et al., 1993; Jayananda et al., 2000; Chardon et al., 2002] (Figure 1). The juvenile bodies, dominated by TTG and sanukitoids, are derived from the melting of young metabasalts or from the differentiation of basaltic liquids [Jayananda et al., 2000; Moyen et al., 2003a]. Heat advection by the 
juvenile plutons commonly led to the genesis of anatectic granites [Jayananda et al., 1995, 2000; Moyen et al., 2003a].

[7] As a result of differential erosion subsequent to postArchean northward tilt $\left(2^{\circ}\right.$, according to Moyen et al. [2003b]), the craton exposes a continuous section through an amphibolite-granulite facies transition of latest Archean age [Hansen et al., 1984a] (Figure 1). This section provides a rare opportunity to study the three-dimensional relationships between deformation, melting, granulite metamorphism, and plutonism [Newton, 1990b] during a major, magmatic accretion event [Jayananda et al., 2000; Chardon et al., 2002].

[8] The Closepet batholith (Figure 1) intruded the Eastern Dharwar craton by the end of the Late Archean tectonometamorphic episode [Jayananda and Mahabaleswar, 1991; Bouhallier, 1995; Jayananda et al., 1995, 2000; Moyen et al., 2003b]. The batholith consists of a N-S elongate main mass extending over $200 \mathrm{~km}$ from $12^{\circ} 30^{\prime}$ to $14^{\circ} 30^{\prime} \mathrm{N}$ (Figure 1) and a group of shallow-level intrusions separated from the main mass by a $\sim 20-\mathrm{km}$-wide gap [Moyen et al., 2003b]. The main mass of the batholith is made of $\mathrm{SiO}_{2}$ poor, co-magmatic, porphyritic monzogranites $(\sim 80 \%$ of the intrusion) and clinopyroxene bearing quartz-monzonites [Jayananda et al., 1995, 2000]. The aureole of the batholith consists of a belt of $\mathrm{SiO}_{2}$-rich diatexites and anatectic granites [Jayananda et al., 1995]. The quartz-monzonites and monzogranites of the main mass were derived from an enriched mantle source by fractional crystallization of a basaltic liquid, in which quartz-monzonites represent early fractionates and monzogranites represent later fractionates [Jayananda et al., 1995, 2000; Moyen et al., 2001].

[9] The quartz-monzonites and monzogranites of the main mass have U-Pb zircon ages of $2518 \pm 5$ and $2518 \pm$ $4 \mathrm{Ma}$, respectively [Jayananda et al., 1995], whereas the anatectic granites from the aureole have a zircon U-Pb age of $2513 \pm 5 \mathrm{Ma}$ [Friend and Nutman, 1991]. Zircon U-Pb geochronology indicates that the migmatitic wall rocks of the batholith at its southern tip developed from $2.9 \mathrm{Ga}$ gneissic protoliths [Mahabaleswar and Peucat, 1988; Mojzis et al., 2003] with $2528 \pm 5$ Ma neosomes [Friend and Nutman, 1991] that went through U-Pb monazite closure temperature by $2500 \pm 5 \mathrm{Ma}$ [Bühl et al., 1983; Mahabaleswar et al., 1995].

[10] In Kabbaldurga quarries, in the area occurring between the orthopyroxene isograd and the charnockitic front (called hereinafter the granulite transition zone; Figure 1), Pichamuthu [1960] reported charnockite patches superimposed on the migmatitic fabrics. This author suggested that the patches resulted from an incipient prograde reaction producing orthopyroxene. This hypothesis has been corroborated by subsequent studies of the incipient charnockites that are interpreted to result from dehydration process operating ahead of a propagating charnockitic front by upward streaming of $\mathrm{CO}_{2}$-rich fluids of deeper crustal or mantle origin [Janardhan et al., 1982].

[11] Paleopressure estimates for late Archean regional metamorphism range from 0.3 to $0.5 \mathrm{GPa}$ along the main mass of the batholith, and to a maximum of $0.8-0.9 \mathrm{GPa}$ in the southernmost parts of the craton, with a corresponding paleotemperatures range from $\sim 400^{\circ} \mathrm{C}$ to $800^{\circ} \mathrm{C}$ [Raith et al., 1983; Hansen et al., 1984b, 1995; Raase et al., 1986].

\section{Structural Anatomy of the Granulite Transition Zone in the Kabbaldurga Area}

\subsection{Fabric Pattern and Kinematics}

[12] The southern tip of the batholith coincides with an area where the charnockitic front, which crosscuts the regional structural grain [Drury and Holt, 1980], has significantly risen with respect to the lower crust located further west (Figure 1). The granulite transition zone is made of metatexite TTG gneisses with superimposed charnockite patches. Peak metamorphic pressures recorded in the granulite transition zone range from $\sim 0.5$ to $0.6 \mathrm{GPa}$, whereas temperatures appear to have been buffered around $750^{\circ} \mathrm{C}$ [Hansen et al., 1984a, 1984b].

[13] The regional migmatitic foliation of the metatexite gneisses is shallowly dipping and acquires moderate to steep dips within north to NNW trending belts that are a few hundreds of meters wide (Figures 2 and $3 b$ ). The coexistence of steep and flat planar fabrics is also observed at the outcrop-scale, steep foliations dipping systematically toward the east (Figures 2b, 3b, and 4a). On E-W cross sections, the shallow fabrics show a systematic dip toward the east (Figures $2 b$ and $4 a$ ). At all scales, fabric patterns on map and cross section (see also section 4) display a sigmoidal trace of the shallow planar fabrics in between steeper foliations (Figures $2 \mathrm{~b}$ and 5). This geometry is indicative of a minor, though systematic and pervasive, east-side-down component of shear sense along the steeply dipping fabrics.

[14] In belts of steep foliation (Figures $2 b$ and 4b), shallow foliations are rotated into upright folds (Figure 4c) and/or transposed (Figures $4 \mathrm{c}$ and 5a). The mineral-stretching lineation is marked by elongate quartz-feldspar and biotite aggregates, or by hornblende or orthopyroxene crystals. This lineation trends parallel to, or at a low angle to, the steep foliations within and outside the charnockites and has a systematic shallow plunge (Figures $2 \mathrm{a}$ and $3 \mathrm{~b}$ ) parallel to the fold axes in the belts of steep foliation.

[15] Throughout the study area, NNE trending dextral shear zones, and NNW trending sinistral shear zones define a conjugate set of strike-slip shear zones (Figure 3c). A series of SE dipping extensional shear zones (Figures 2a and $3 d$ ), tens of centimeters to tens of meters long, affects both the flat and steep migmatitic fabrics (Figures $4 \mathrm{e}$ and $4 \mathrm{f}$ ). Steep foliations and upright folds are locally refolded about subhorizontal axial surfaces and sheared parallel the SE dipping extensional shears (Figures $4 \mathrm{e}$ and $5 \mathrm{a}$ ).

[16] Throughout the granulite transition zone, steep and shallow planar fabrics are systematically boudinaged in a SSE horizontal direction (Figures $4 \mathrm{~b}, 4 \mathrm{~d}$, and $4 \mathrm{f}$ ). This lengthening direction is consistent with the orientation of the subhorizontal, SSE trending mineral-stretching lineation and SE dipping extensional shear zones (Figures 2a, 3b and 3d). 


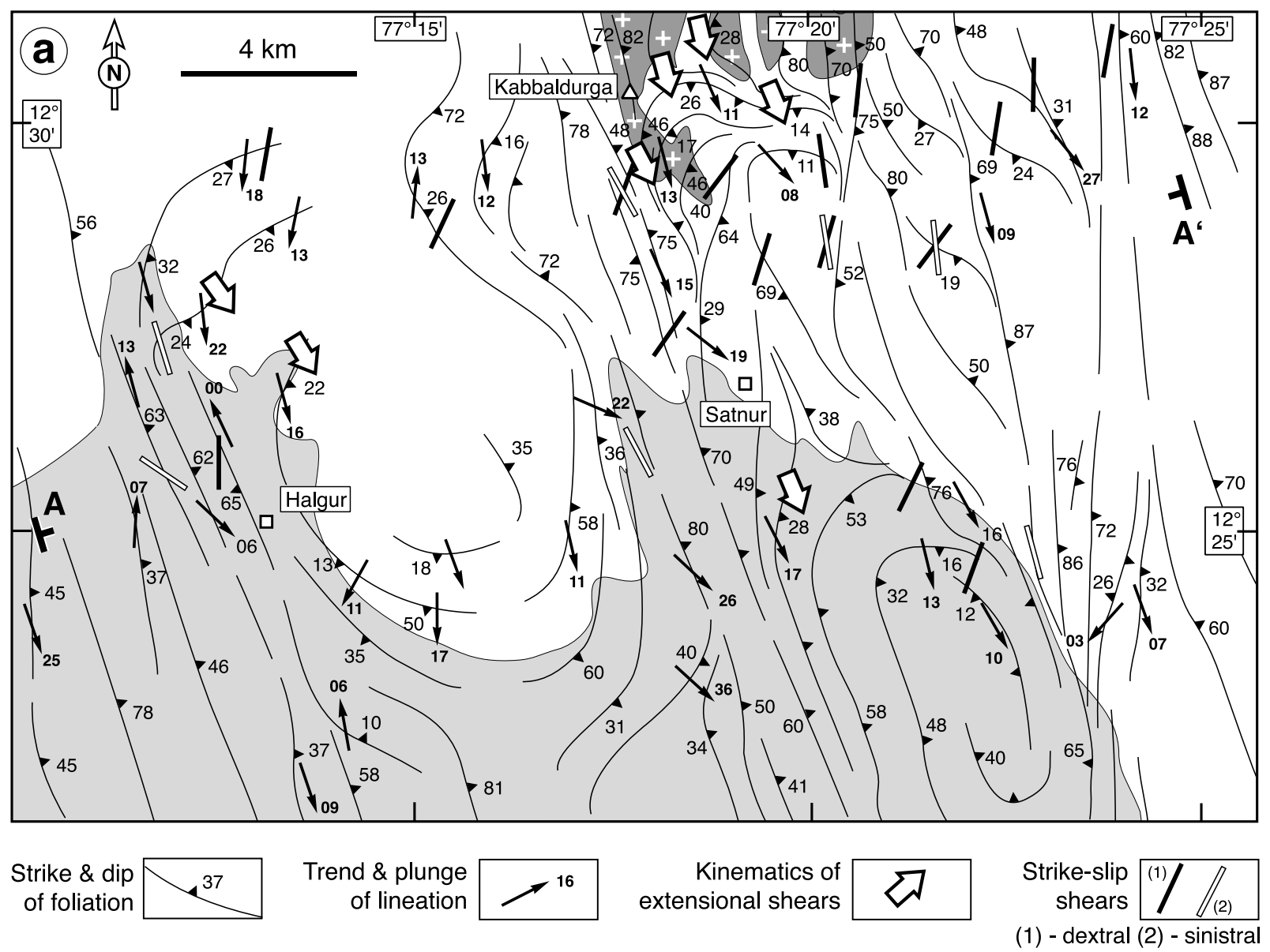

(b)

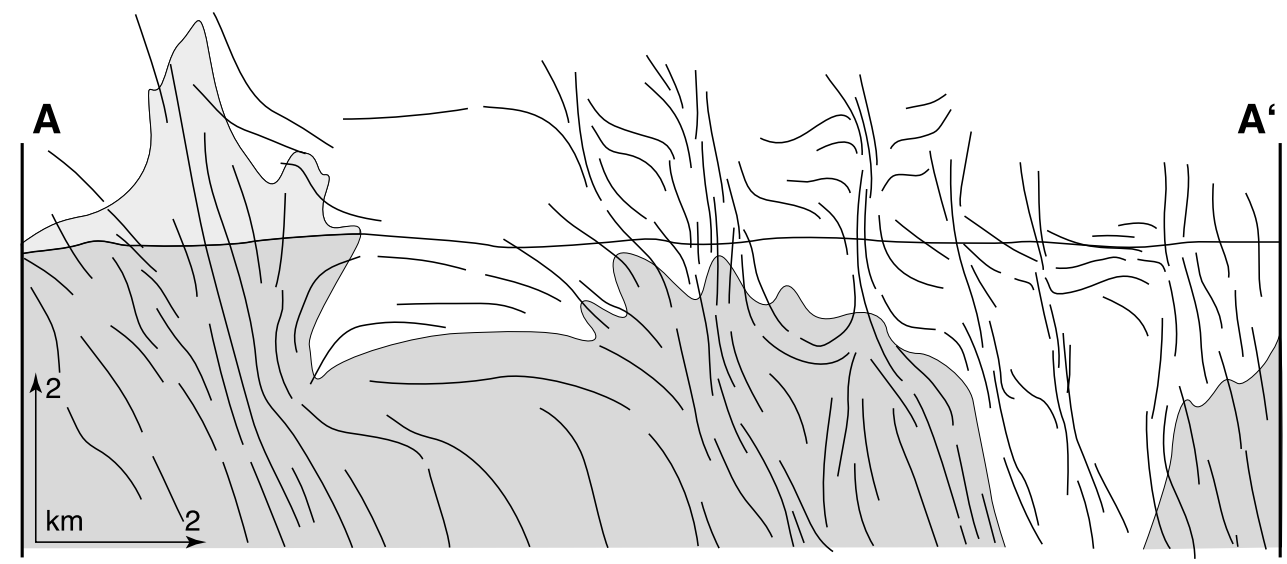

Figure 2. (a) Detailed structural map of the granulite transition zone in the Kabbaldurga area (location in Figure 1). The boundary of the charnockites (shaded) is modified after Mahabaleswar et al. [1995]. (b) Cross section of the study area.

\subsection{Relations Between Melts and Deformation}

[17] The flat and steep planar fabrics are at least partly coeval as they developed during the same partial melting episode. Melt products are abundant throughout the granulite transition zone. They include (1) neosomes of the metatexite gneisses, (2) concordant and discordant veins of fabric-free anatectic pink and grey granite, and (3) concordant and discordant veins of hornblende bearing tonalite. Veins and neozomes can be followed from one type of fabric to the other (Figure 4a). Coalescent fabric-free veins are hosted by both types of planar fabrics (Figures $4 a-4 c$ ); 


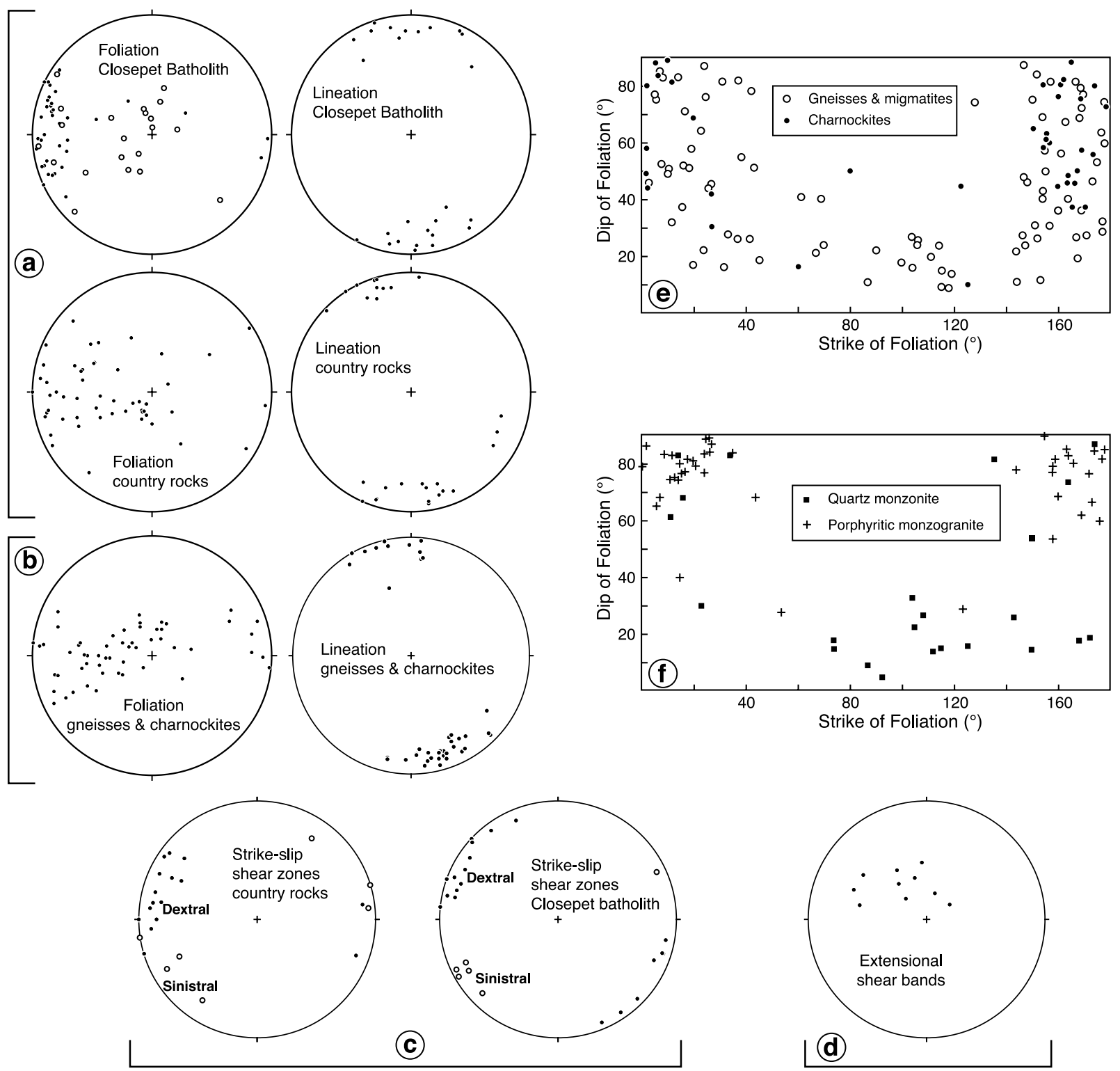

Figure 3. (a) Fabric measurements in the Closepet batholith and its country rocks (map area of Figure 6). For the batholith, open circles represent banding and foliation in the quartz-monzonite, and solid circles represent foliation measurements in the porphyritic monzogranite. (b) Fabric measurements across the granulite transition zone (map area of Figure 2a). (c) Strike-slip shear bands (entire study area). Within the Closepet batholith, measurements group high-temperature, melt-filled shear bands (dextral and sinistral) as well as shear planes of CS fabrics (exclusively dextral; see Figure 6c). (d) Extensional shear bands. (e, f) Diagrams showing the relative attitude of the strike and dip of foliations for the different types of rocks (entire study area; equal area, lower hemisphere projections).

concordant veins and neosomes from the shallow foliation appear to feed granitoid filled belts of steep fabrics. The shallow foliation is preserved over large volumes of pervasively partially molten crust of the granulite transition zone (i.e., it has not been entirely overprinted by the steep foliation). This configuration further supports the idea that both steep and flat planar fabrics were being activated contemporaneously.
[18] Fabric-free granitoid material collected from neosomes of the shallow and steep fabrics are trapped in boudin necks that form veins after they coalesce (Figure 4d). Fabric-free granitoid material is also systematically hosted by the strike-slip and extensional shear zones acting as melt collectors (Figures $4 \mathrm{e}$ and $4 \mathrm{f}$ ). To summarize, activation of the shallow and steep planar fabrics, boudinage and shearing along the strike-slip and extensional shear zones took 

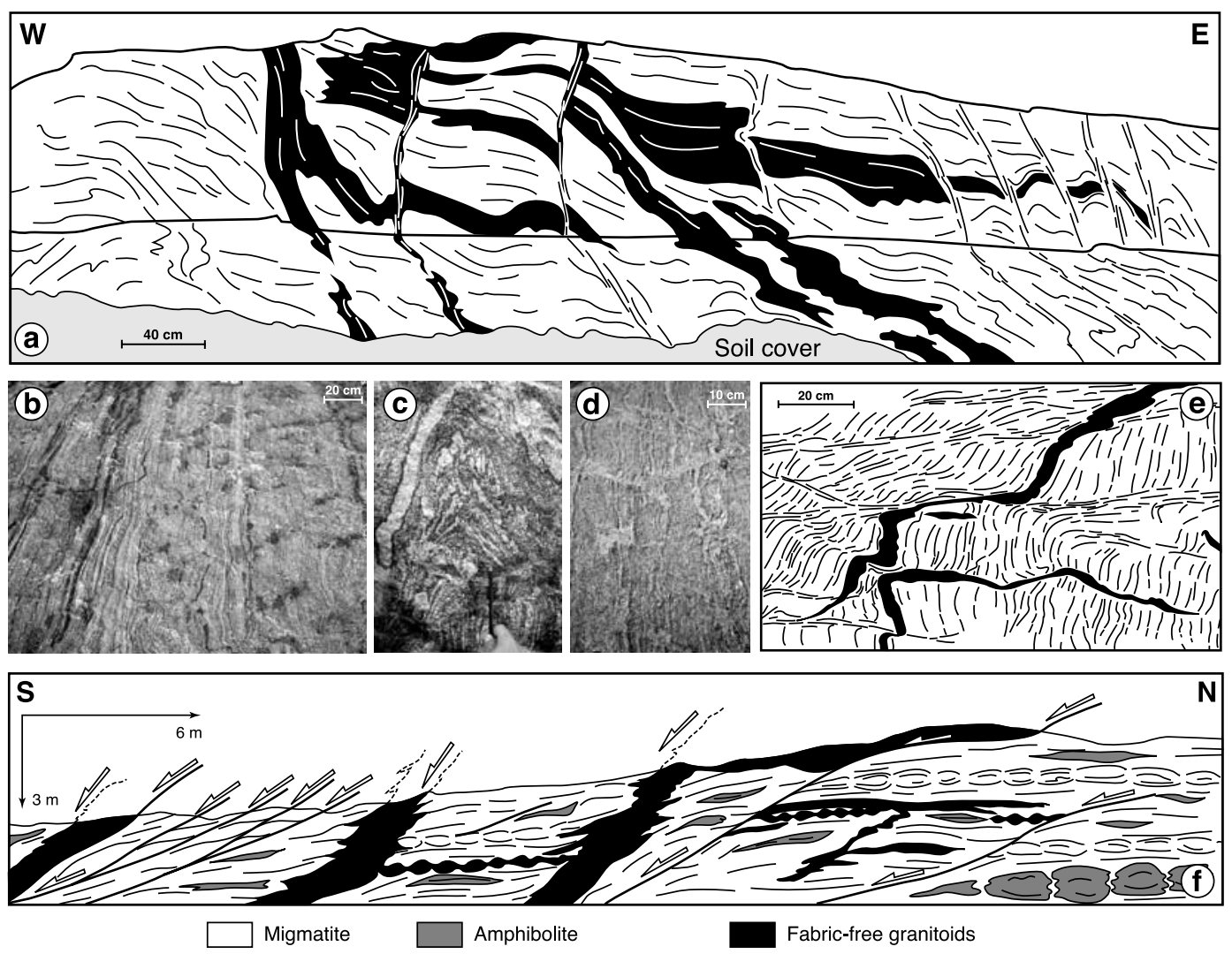

Figure 4. Structural patterns of the granulite transition zone (area of Figure 2a). (a) Typical fabric interference in the migmatites south of Tenginkal (Figure 6). The vertical section is perpendicular to the mineral-stretching lineation. (b) Vertical foliations trending $\mathrm{N} 160^{\circ} \mathrm{E}$, bearing a strike-parallel, mineralstretching lineation. Charnockite patches are superimposed on melt-filled boudin necks. (c) Upright folds with horizontal axes trending parallel to the mineral-stretching lineation. (d) Vein array collecting granitic melts from boudin necks (XZ plane). Figures $4 \mathrm{~b}-4 \mathrm{~d}$ are from the same outcrop of the southern Kabbaldurga quarries. (e) South-looking view of the synmelt extensional shear zones affecting the vertical migmatitic foliation (section at a high angle to the slip direction on the shear bands) (central Kabbaldurga quarries). (f) Sketch of a vertical quarry cut, easternmost Kabbaldurga quarries (charnockite patches omitted).

place at the time of regional partial melting and transfer and emplacement of anatectic and tonalitic melts.

\subsection{Implications (Figure 5b)}

[19] The structural pattern documented at various scales in the granulite transition zone reflects a bulk homogeneous strain field developed during regional partial melting and melt transfer through the crust. It results from the coeval activation of two sets of planar fabrics, a conjugate set of strike-slip shears and extensional shears. All these structural elements share the same direction of horizontal elongation. This strain field results from (1) E-W horizontal shortening (recorded by the steep planar fabrics and conjugate strikeslip shear zones), (2) coeval vertical shortening (recorded by the shallow planar fabrics and extensional shears), and (3) N-S horizontal stretching (recorded by horizontal, strike-parallel boudinage and stretching lineations, conjugate strike-slip and extensional shear zones). Such a struc- tural pattern is indicative of bulk, horizontal, constrictional deformation $\left(\lambda_{1}>1>\lambda_{2} \geq \lambda_{3}\right)$.

\section{Strain Pattern Within and Around the Closepet Batholith}

\subsection{Structural Geometry}

[20] In map view, the southernmost part of the Closepet batholith has a wedge shape with a N-S trending eastern margin and a NNW trending western margin (Figure 6). South of Tenginkal, where the intrusion is the narrowest, the contours of the batholith become digitated (Figure 6) and the intrusion is principally made of quartz monzonites.

[21] A NNW trending line parallel to the western margin of the batholith separates two foliation map patterns. SW of that line, the foliation pattern is the continuation of that of the granulite transition zone shown on Figure 2. It is characterized by coexisting steep NNW trending foliations 

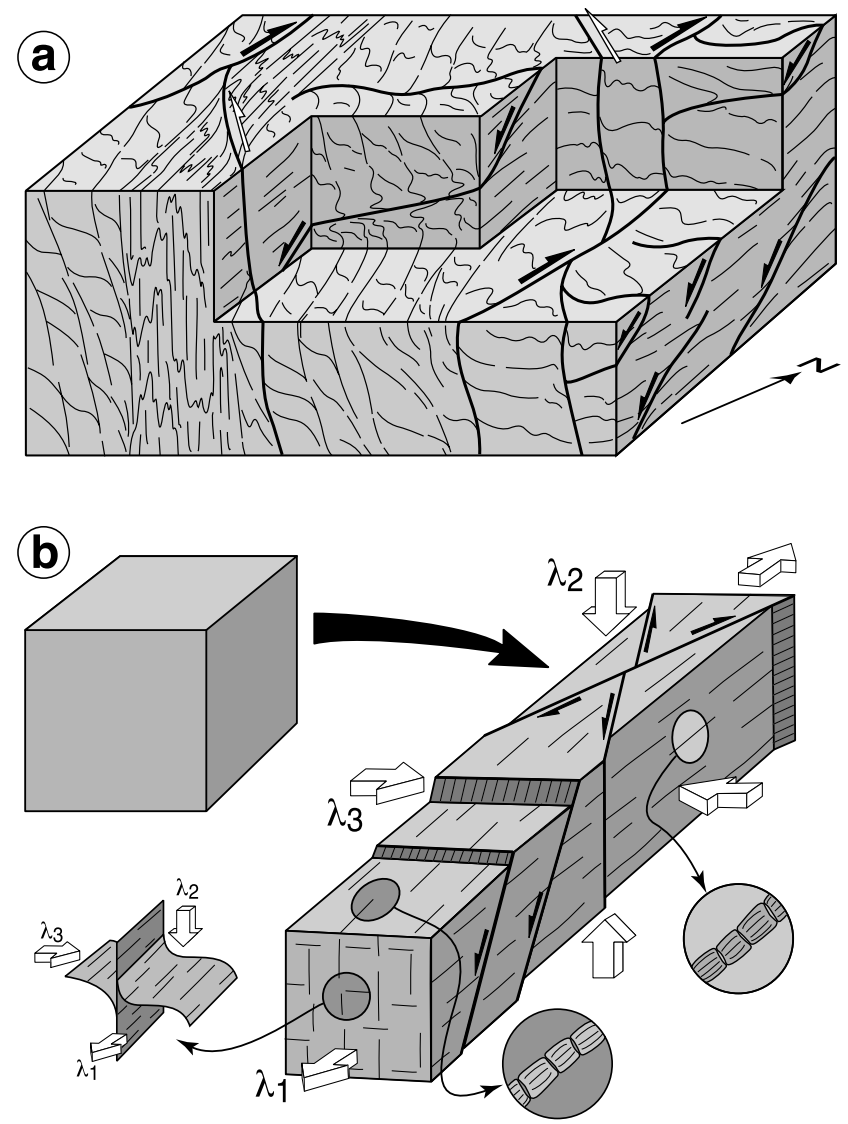

Figure 5. (a) Block diagram summarizing the relationships between migmatitic fabrics and shear zones in the granulite transition zone, as best exemplified in the Kabbaldurga quarries. (b) Synthetic representation of bulk, horizontal constrictional strain in the granulite transition zone. Strain is not isovolumetric given the amount of synkinematic granitic and tonalitic material trapped in each element of the structural pattern.

and shallow west to NW trending foliations, with preferential preservation of shallow planar fabrics in the Chanapatna area (Figure 6a). NE of that line, foliations are consistently north trending with mainly steep to moderate eastern dips with several tracts of shallower NW to NNW trending fabrics. NE trending extensional melt-filled shear zones affect the shallow fabrics in the migmatites, especially to the West of the batholith.

[22] Planar fabrics within the batholith consist of a magmatic banding and/or the mineral fabric of the quartz monzonites and by the preferred orientation of feldspar phenocrysts in the monzogranites (Figures $7 \mathrm{a}$ and $7 \mathrm{~b}$ ). The batholith contains both the shallow and steep planar fabrics of its host migmatites. The porphyritic monzogranite facies has almost exclusively steep NNE to NNW trending foliations (Figures 3a, 3f, and 7b). The early quartz-monzonitic facies has a gradation of foliation orientation from NNE to NNW trending and steeply dipping, to E-W trending and shallowly dipping (Figures $3 \mathrm{a}$ and 3f) as exemplified in the southernmost tongues of the batholith (Figures $7 \mathrm{a}$ and $7 \mathrm{e}$ ).

[23] In the vicinity of the contact between the country rocks and the batholith, foliation in the wall rocks parallels that of the intrusion so that planar fabrics in the batholith are the continuation of those of its wall rocks, even where foliation crosscuts the contact at a high angle (Figure 7e). North of Tenginkal, wall rocks foliation is deflected and steepened to become concordant with the strain aureole of the batholith. It is also concordant with the batholith-wall rock contact and with the internal planar fabric of the batholith (Figure 7e). Foliation deflection toward the batholith proceeds by downwarping along the western margin of the intrusion and by upwarping along its eastern margin (Figure 7e). This cross-section fabric deflection pattern mimics that documented in the granulite transition zone at various scales, with the steep planar fabric (i.e., the batholith) flanked by dragged, shallower planar fabrics (i.e., country rocks fabrics) (comparison of Figures 5a and 7e).

[24] Stretching mineral lineations in the country rocks and mineral lineations in the batholith (marked mainly by feldspar phenocrysts) trend dominantly SSE, and plunge shallowly (Figures 3a and 6b).

[25] The batholith and its country rocks are affected by a conjugate strike-slip shear zone pattern with a more prominent NNE to NE trending dextral set comprising ductile, melt-bearing shear zones as well as belts of CS fabrics in the porphyritic monzogranites (Figures 3c, 6c, and $7 b-7 d$ ). Dextral shear planes that dominantly trend to the NNE in the migmatites tend to be deflected toward NE strikes within the batholith (Figure 6c).

\subsection{Structural Relations at Higher Crustal Levels}

[26] We have carried out structural analyses along E-W corridors across the main mass of the batholith and its country rocks at two different paleodepths above the granulite transition zone (Figure 7e, sections 3 and 4). The results are consistent with those obtained in the Ramanagaram area (Figures $6 \mathrm{a}$ and $7 \mathrm{e}$, section 2 ) and document the cylindricity of the structures, fabric patterns, and batholithcountry rock relations along the main mass of the batholith (Figure 7e). The batholith and its country rocks are affected by the same conjugate strike-slip shear zone pattern as that described further to the South. Within the country rocks, south to SE dipping, melt-bearing extensional shear zones are also systematically documented.

\subsection{Structural Relations at Lower Crustal Levels}

[27] We have compiled a foliation trajectory map over a large portion of the lower crust underlying the Closepet batholith on the basis of the detailed structural map of Sugavanam [1984], SPOT satellite image interpretation by Bouhallier [1995], and new satellite image analysis (Figure 8a). These data allow documentation of a zone of fold interference patterns in between (1) steep N-S trending foliations dragged into NNW trending sinistral shear zones in the BR Hills massif to the west and (2) straight NNE trending, steeply east dipping fabrics, to the east (Figures 8a and $8 b)$. 


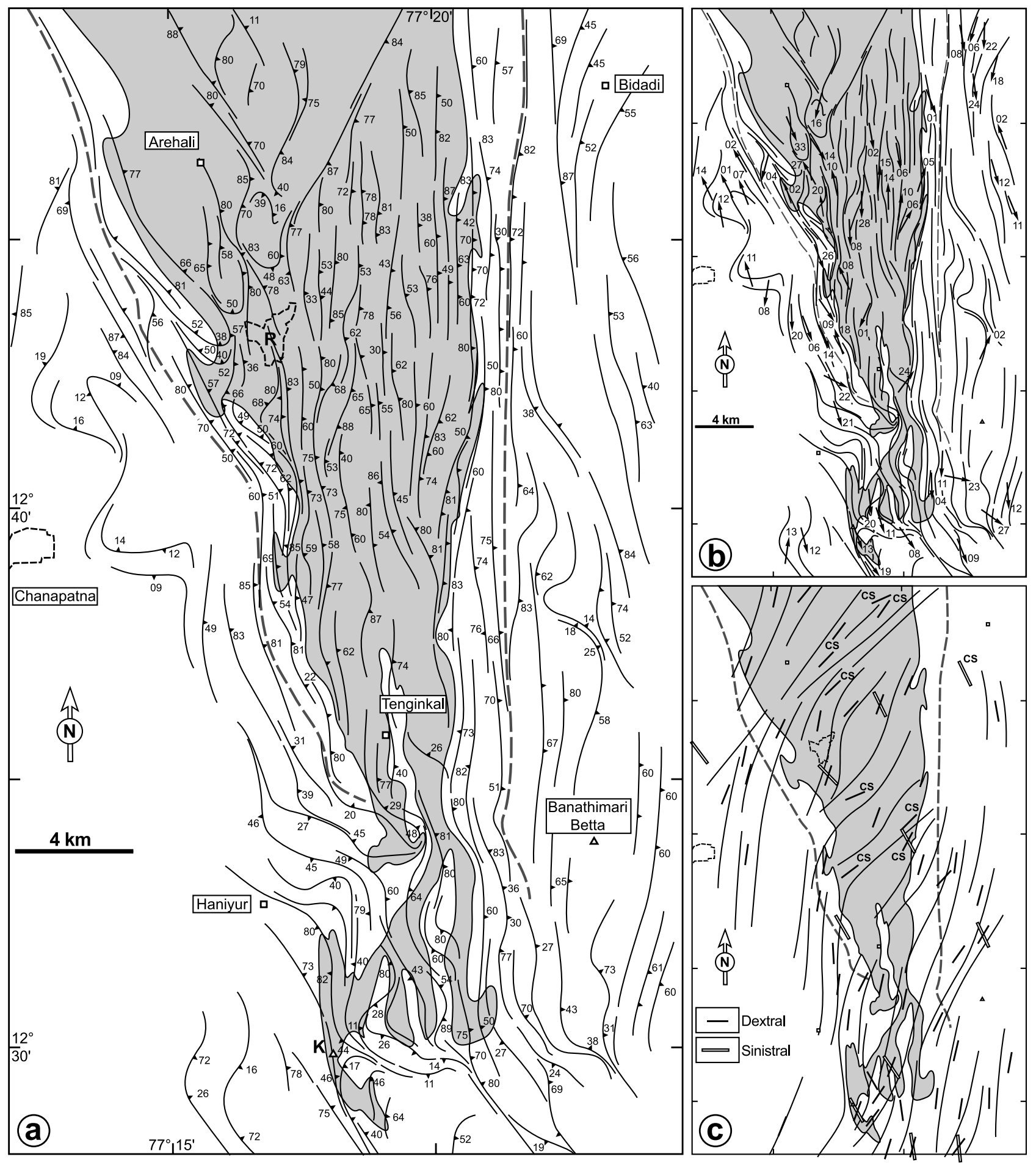

Figure 6. Structural maps of the southern part of the Closepet batholith (drawn in grey) and its country rocks. Thick dashed line represents the boundary of the aureole of the batholith. (a) Foliation measurements from the present study (mainly) and from Suryanarayana [1961, 1964]). (b) Mineralstretching lineation measurements superimposed on the foliation trajectories (measurements inside the batholith are from Suryanarayana [1964] and the present study). (c) Trend of the strike-slip shear zones. Shear planes from CS fabrics are indicated. Thin lines represent the trajectories of the dextral shear planes. Geological contacts are from Suryanarayana [1961] and the present study. Location given in Figure 1. R, Ramanagaram (formerly Closepet); K, Kabbaldurga. 

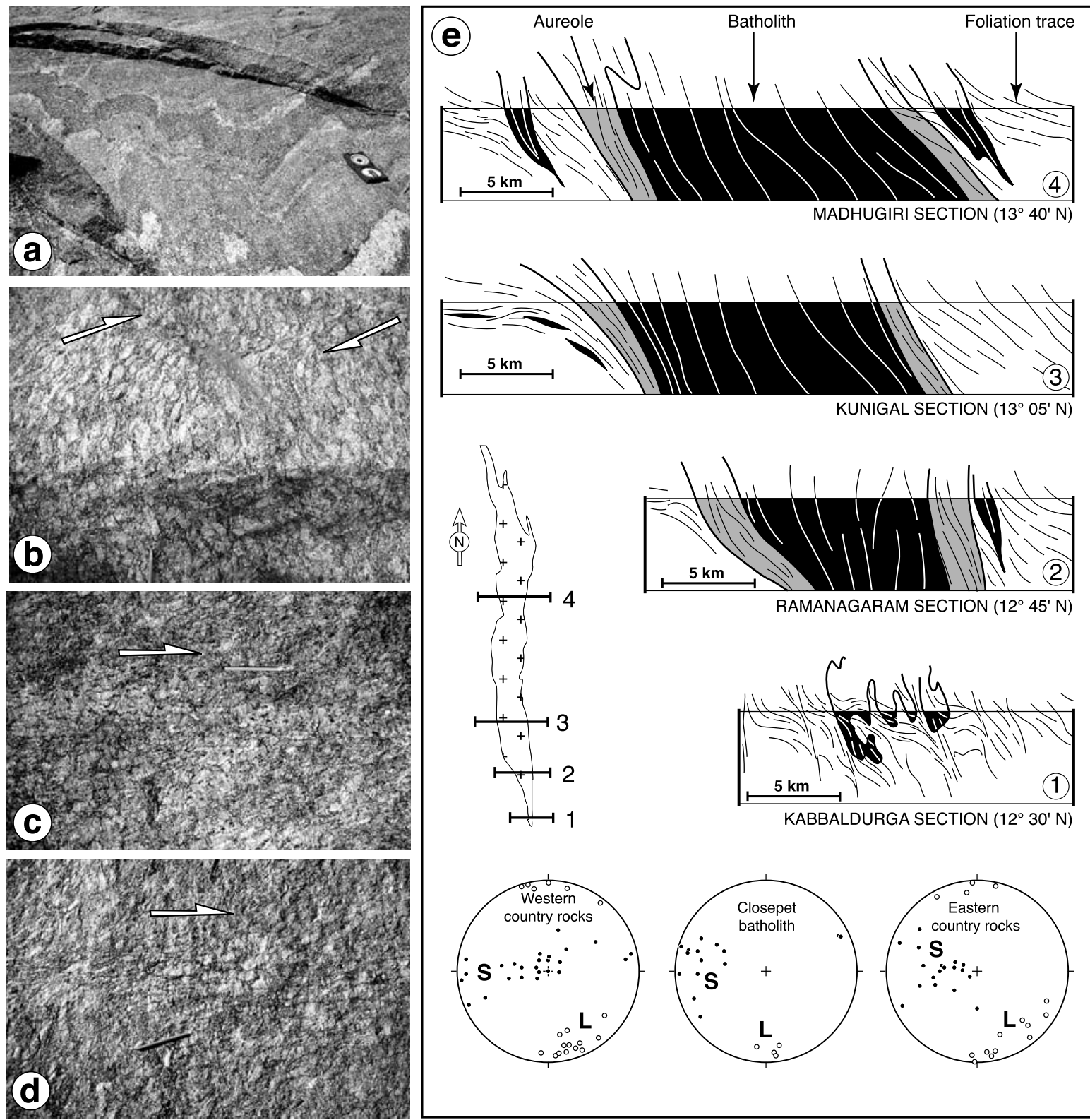

Figure 7. Fabric and shear zone patterns in the Closepet batholith. (a) Flat banding in the quartz monzonite. (b) Typical steeply east dipping foliation and NE trending belt of CS fabrics in the porphyritic monzogranite. (c, d) Two stages in the development of NE trending dextral shear zones in the porphyritic monzogranite. At an early stage, high-temperature shearing proceeds by collection and tiling of phenocrysts within the future shear plane (Figure 7c). Later-stage shearing proceeds by activation of incipient C surfaces (Figure 7d). (e) Serial cross sections of the main mass of the Closepet batholith. Stereoplots show data collected along sections 3 and 4 (equal area, lower hemisphere projections). $\mathrm{S}$, foliation; L, mineral-stretching lineation.

[28] The interference zone results from pinching off of the fabric pattern documented in the granulite transition zone by steep, deeper crustal planar fabrics of contrasting orientation. The wedge-shape of the interference zone and the consistent shallow plunge of lineations and microfold axes in the interference zone [Sugavanam, 1984] suggest that it is a horizontal isotropic line [Brun, 1983]. This line would be a shallowly plunging fabric triple point resulting from the interplay of batholith expansion and regional shortening [Brun and Pons, 1981]. The interference zone could also be the signature of a tectonic boundary within the Eastern Dharwar craton, which enhanced late focused 

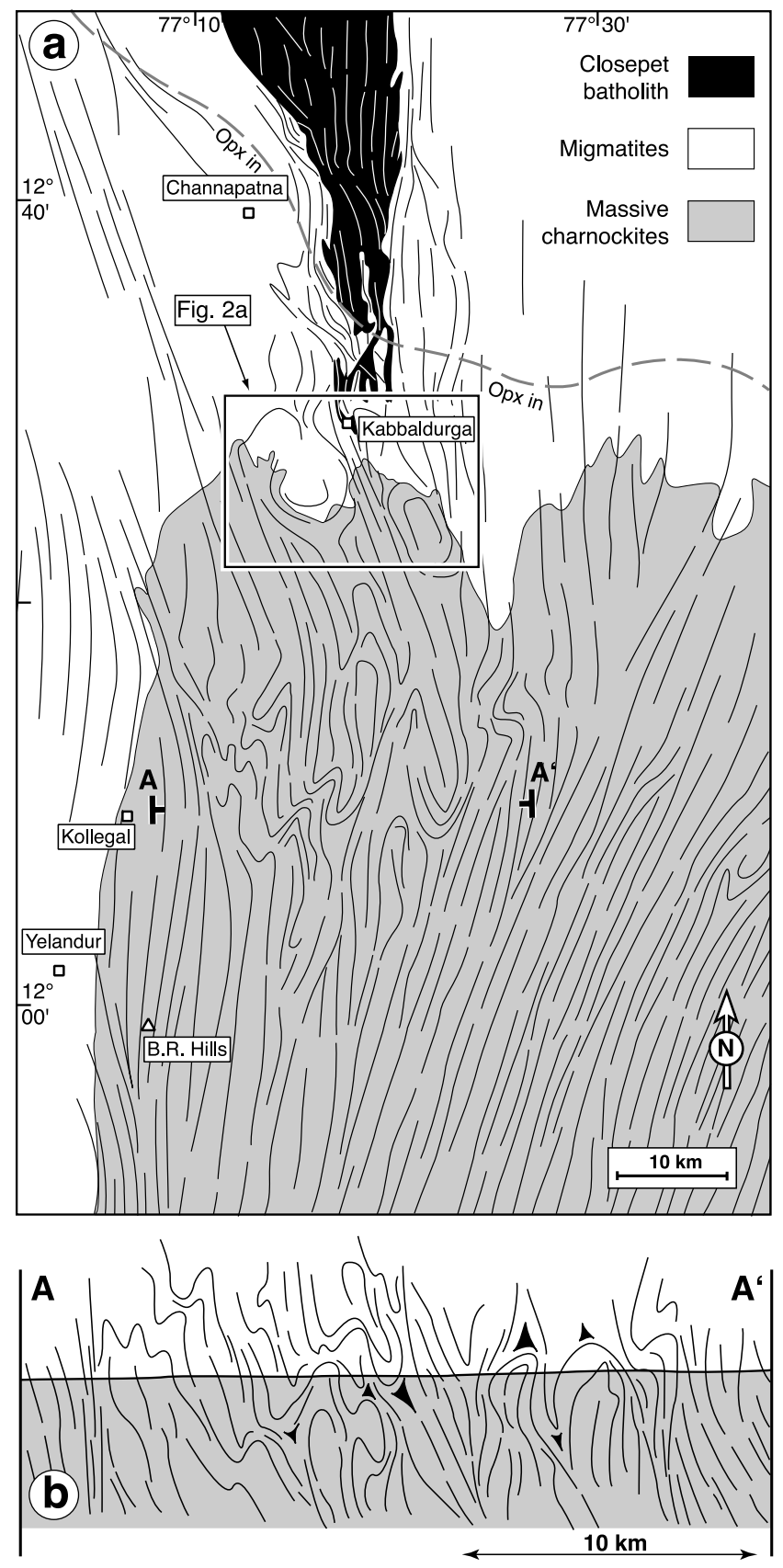

Figure 8. (a) Regional foliation trajectory map of the granulite transition zone (location in Figure 1), derived from field measurements, geological mapping, and SPOT images analysis. Sources are Suryanarayana [1961], Sugavanam [1984], Bouhallier [1995], and the present study. There is good agreement between field-based map geometry of the structural trends and photointerpretation. The map by Sugavanam [1984] comprises most of the folded area. (b) Sketch cross-section geometry of the fold pattern in the interference zone based on field mapping and field measurements of Sugavanam [1984]. magmatic accretion in the Closepet batholith. The two interpretations do not exclude each other.

\section{Interpretation}

\subsection{Symmetry of the Strain Pattern}

[29] The fabric pattern documented within and around the batholith is homogeneous and strikingly similar to that documented within the granulite transition zone; lineations are clustered in the SSE direction and the planar fabrics grade from flat to steeply east dipping within and outside the batholith (comparison of Figures $3 \mathrm{a}$ and $3 \mathrm{~b}$ ). This indicates that bulk constrictional deformation documented in the granulite transition zone (Figure 5) extends further up in the crust and affects the migmatites and the batholith.

[30] The radial distribution of the poles to the planar fabrics with respect to the main stretching axis attests to the constrictional nature of the bulk strain ellipsoid (Figure 9a) and is consistent with a bulk fabric pattern of monoclinic symmetry (Figure 9b). Planar fabrics and conjugate strikeslip shear zones throughout the study area are systematically east dipping, consistent and kinematically compatible with the monoclinic symmetry of the fabric pattern (Figures $3 a-$ $3 \mathrm{c}$ and 9c). There is, however, a systematic obliquity between the trend of the stretching lineation and the strike of the foliation $\left(17^{\circ}\right.$, clockwise, indicative of a southern pitch; Figure 9c). There is also a systematic obliquity between the stretching lineation and the mean intersection lineation $\left(11^{\circ}\right.$, clockwise; Figure 9c). Moreover, the strike of the mean extensional shears is clearly oblique (instead of perpendicular) to the mean foliation trend (Figure 9c).

[31] The planar and linear fabrics, the strike-slip shear zones and the extensional shear zones developed and coexisted at a time when regional partial melting and melt transfer were taking place through the crust. Therefore, considering (1) the monoclinic symmetry of the fabric pattern, (2) the systematic east-side-down apparent shear along the steeply east dipping fabrics, (3) the southern pitch of the main SSE trending lineation, and (4) the systematic southeastern dip of the extensional shear zones, the bulk strain pattern is interpreted to result from slight but diffuse dextral transtension, which is in agreement with the prolate shape of the bulk strain ellipsoid [e.g., Dewey et al., 1998].

\subsection{Batholith Emplacement Mechanism}

[32] The main mass of the batholith is at least $150 \mathrm{~km}$ long (map length), has a maximum width of $15 \mathrm{~km}$ and extends vertically over a maximum paleodepth range of only $8 \mathrm{~km}$ (deduced from paleopressure estimates at its tips [Hansen et al., 1984b, 1995; Raase et al., 1986]). On the basis of its cross-section geometry (Figure 7e) and map shape (Figure 1), and given the $2^{\circ}$ of northward solid body tilt of the craton, the main mass of the batholith may be approximated as a highly elongate, monoclinic parallelepiped consistent with both (1) the symmetry of the bulk fabric 

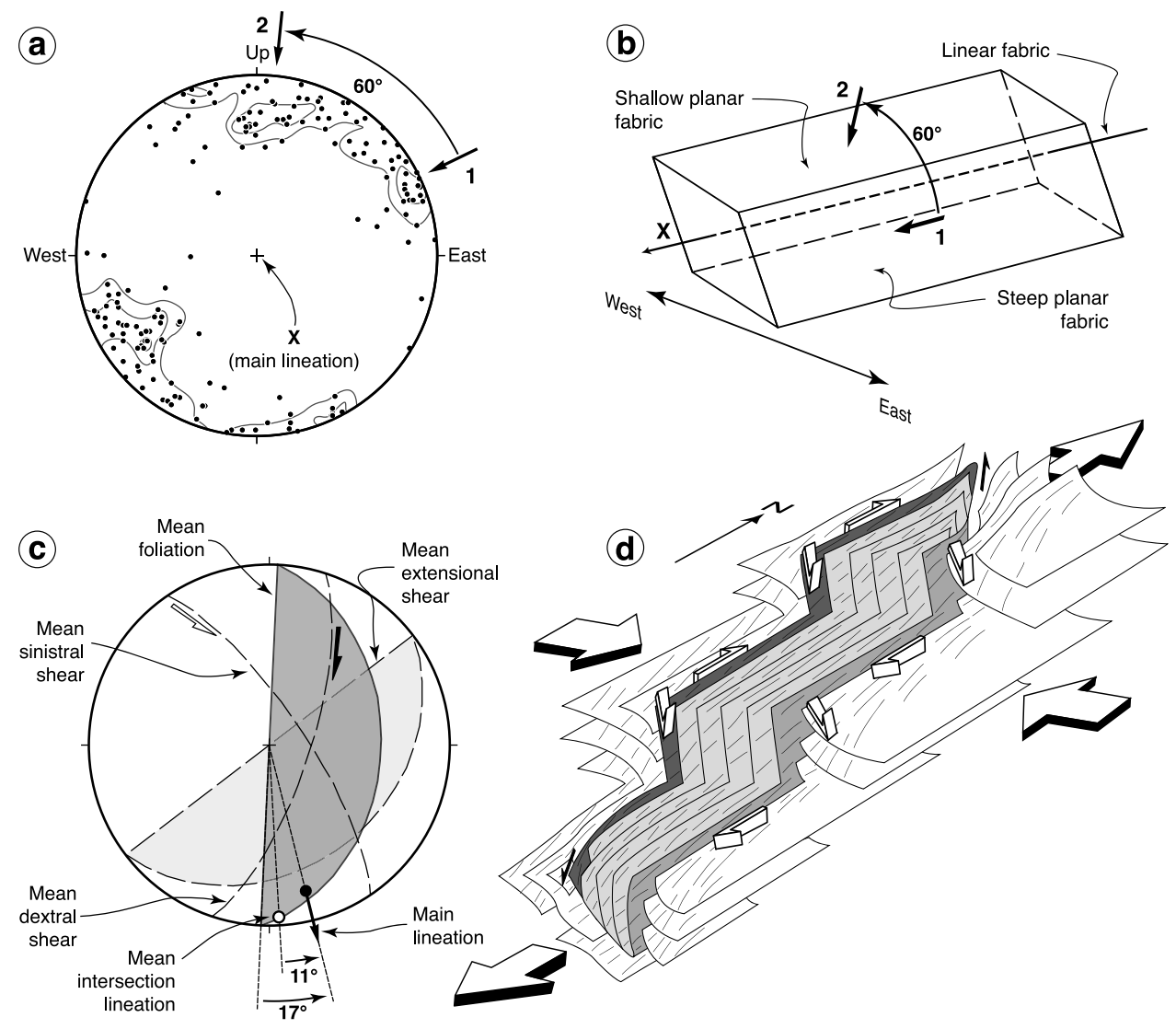

Figure 9. Synthesis of the regional structural elements and emplacement model of the Closepet batholith. (a) Poles to foliation planes (data set from Figure 3). Data are rotated so that the main mineralstretching lineation $(166,18)$ is vertical and pointing upward. Two main pole trends are identified (arrows), corresponding to the main steep (point 1) and shallow (point 2) planar fabrics. (b) Symmetry of the bulk fabric pattern based on Figure 9a and field observations. (c) Orientation of the main structural elements (lower hemisphere, equal area projections). (d) Kinematic pattern of emplacement of the main mass of the Closepet batholith. Batholith planar fabrics are in grey. Thin lines are lineation traces.

pattern (Figure 9b) and (2) the prolate shape of the bulk strain ellipsoid.

[33] The intrusion expanded within a zone of diffuse, 3-D strain partitioning (Figure 9d). Across-strike growth of the intrusion was enhanced by the dextral transtensional component of regional deformation, whereas the batholith expanded longitudinally in the direction of horizontal constrictional flow (Figure 9d).

[34] Outside the batholith, there is a low angle between the conjugate strike-slip shear zones and the steep regional fabrics (Figures 2a and 6c). Within the batholith, this angle increases, especially for the dextral CS fabricsbearing shear zones (Figure 6c). This indicates dominant fabric-parallel stretching assisting horizontal constrictional flow and later shearing at a high angle to the steep fabrics in response to cooling [Gapais, 1989] of the intrusion (see also Figure 10a). The CS fabrics are consistent with the conjugate strike-slip shear zone pattern documented on various scales throughout the Eastern
Dharwar craton (Figures 1 and 10a) [Chardon et al., 2002].

\section{Regional Deformation Patterns}

[35] The regional structural analysis we have carried out in the Eastern Dharwar craton reveals the pervasive occurrence of the planar/linear fabric pattern documented around the batholith. The regional fabrics pattern consists of shallowly east dipping foliations variably overprinted by steeply east dipping foliations (Figure 10b). The stretching mineral lineation is nearly horizontal and strike-parallel. A macroscopic conjugate strike-slip shear zone pattern comparable to the craton-scale shear zone array is also systematically documented (Figure 10a; see also Chardon et al. [2002]). Most parts of the Eastern Dharwar craton therefore seem to have undergone the same deformation as that documented around the Closepet batholith.

[36] Large tracts of gneisses with shallow fabrics and concordant juvenile sills dated at $2.56 \mathrm{Ga}$ (D. Chardon et 


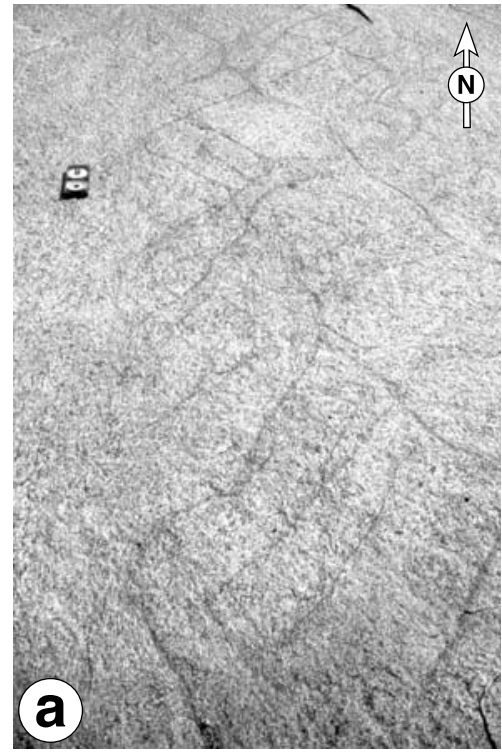

SW

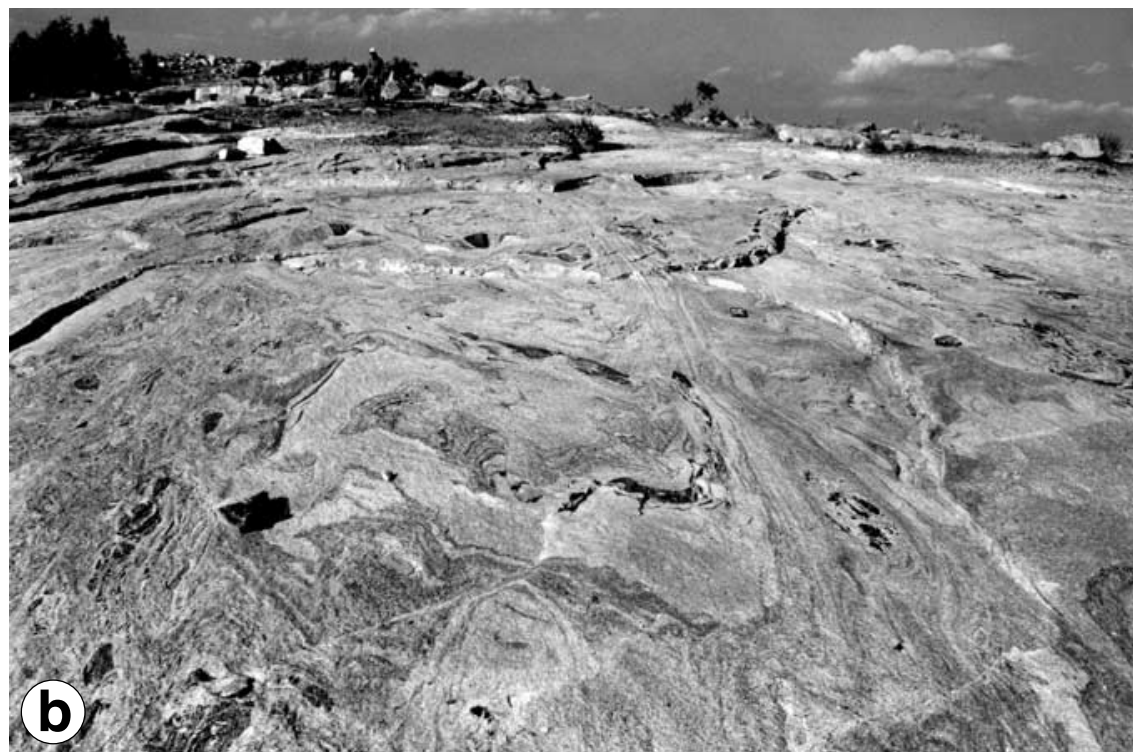

NE
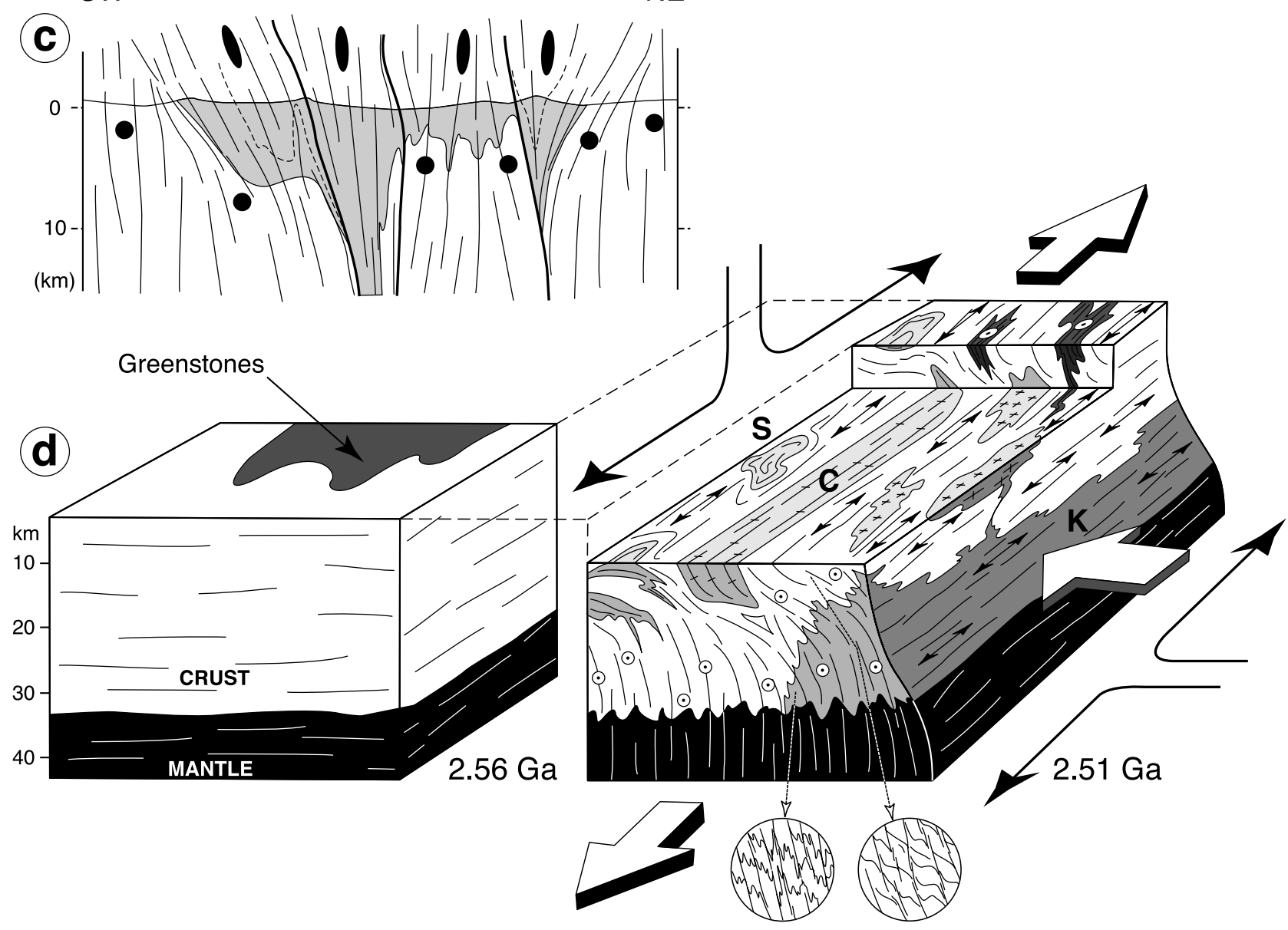

Figure 10 
al., manuscript in preparation, 2008) are preserved in the Eastern Dharwar craton, especially in between the Closepet batholith and the Chitradurga greenstone belt (type location is Sira; Figure 1). In the Krishnagiri area (Figure 1), both the steep and shallow fabrics described above affect a large juvenile tonalitic migmatitic complex with a U-Pb zircon age of $2530 \mathrm{Ma}$ [Peucat et al., 1993].

[37] Within and around greenstone belts, deformation results from the interplay of two strain patterns coeval with emplacement of 2.55-2.53 Ga juvenile felsic plutons [Chardon et al., 2002]. The first strain pattern reflects bulk horizontal, pure shear deformation recorded in the metatexites and plutons by the steep planar fabrics, horizontal lineations and conjugate strike-slip shear zone patterns (Figure 10a). The second strain pattern results from dip-slip shearing at the granite-greenstone contact and vertical stretching within the greenstone belts [Chardon et al., 2002] (Figure 10c). Interplay of these two strain patterns reflects partitioning between regional horizontal pure shear and sagduction of and/or transpression within the greenstone belts (Figure 10c; see also Mukhopadhyay and Matin [1993], Chadwick et al. [1996], and Matin [2006]).

[38] A kinematic model for the structural development of the Eastern Dharwar craton during juvenile magmatic accretion between 2.56 and $2.51 \mathrm{Ga}$ should therefore combine (1) early horizontal flattening and superimposition of steep foliations on shallow foliations, (2) horizontal constrictional flow, (3) transpression and/or sagduction of greenstones, and (4) horizontal pure shear.

\section{Discussion}

[39] The structural, kinematic, and plutonic pattern documented in the vicinity the Closepet batholith and over large areas of the Eastern Dharwar craton is indicative of horizontal constrictional deformation affecting the midcrust and lower crust. This deformation occurred during juvenile magmatic accretion and pervasive partial crustal melting between 2.56 and $2.51 \mathrm{Ga}$ [Jayananda et al., 2000; Chardon et al., 2002]. Horizontal constriction is interpreted to result from crustal-scale, lateral gravity- and tectonicdriven flow [Rey et al., 2001] perpendicular to the direction of shortening (Figure 10d).
[40] The spatial and temporal tectonoplutonic pattern of the Eastern Dharwar craton suggests horizontal flattening of pre-2.56 Ga crust during emplacement of the first batches of juvenile felsic melts, and development of steep foliations until $2.51 \mathrm{Ga}$. Early juvenile accretion $(2.56 \mathrm{Ga})$ proceeded by emplacement of sills (Sira-type juvenile crust) concordant with the flat fabrics. Late intrusions $(2.51 \mathrm{Ga})$, such as the Closepet batholith, intruded as funnels into a constrictional and fully developed interference pattern between shallow and steep foliations (Figure 10d). The transtensional component of constrictional flow allowed expansion of such juvenile felsic intrusions. Juvenile complexes emplaced between 2.55 and $2.53 \mathrm{Ga}$, such as the Krishnagiri-type crust, have intermediate geometries in between that of horizontal sills and that of funnels, owing to long-lived evolving fabric interference and remelting (Figure 10c).

[41] Granulites of the Dharwar craton show nearly isobaric cooling paths [Raith et al., 1983]. They have undergone regional slow cooling attested by the wide range of late Archean $\mathrm{U}-\mathrm{Pb}$ zircon and titanite dates $(2550-2510 \mathrm{Ma})$ in the midcrust and lower crust. Furthermore, greenstones show monotonous, low-grade metamorphic assemblages at high structural level in the craton. These spatial and temporal metamorphic patterns preclude crustal thickening as the cause of regional HT-LP metamorphism [Chardon et al., 2002]. Pervasive horizontal stretching of the migmatitic crust of the Eastern Dharwar craton and the predominance of strike-slip shearing within the regional shear zones [Drury et al., 1984; Chardon et al., 2002] attest to the dominance of horizontal movements and flow during the late Archean tectonothermal event. The first-order metamorphic and structural patterns of the Eastern Dharwar craton therefore suggest limited and/or negligible thickening in response to 2.56-2.51 Ga tectonoplutonism [Chardon et al., 2002].

[42] We consider thinning due to horizontal constrictional flow to have acted to maintain a nearly stable crustal thickness by compensating volume increase due to juvenile magmatic accretion in a pervasively melted crust that could not sustain thickening. Constrictional flow also contributed to compensating thickening within and around greenstone belts owing to transpression and/or sagduction (Figure 10). These arguments point to a tectonic style that may be

Figure 10. Typical strain patterns of the Eastern Dharwar craton to the east of the Closepet batholith and kinematic framework of late Archean tectonism. (a) Strain pattern in migmatitic gneisses to the east of the Kolar greenstone belt (location in Figure 1). Deformation is partitioned between (1) conjugate strike-slip shearing, (2) homogeneous, horizontal plane strain in lower strain lozenges, and (3) N-S flow within the foliation belt underlying the compass. (b) Association of shallowly east dipping foliations and belts of steeply east dipping foliations (east of the Kolar greenstone belt, Figure 1). (c) Fabric pattern of the Sandur granite-greenstone terrain lying structurally above the main mass of the Closepet batholith at $\sim 15^{\circ} \mathrm{N}$ (Figure 1) (modified from the map and cross section of Chadwick et al. [1996]). Greenstones are in grey. Foliation traces are shown as thin lines, bedding is shown as dashed lines, and shear zones are shown as thick lines. Ellipses underline downdip stretching within the greenstones and horizontal stretching in granitoids and migmatites. (d) Late Archean development of bulk, horizontal plain strain deformation and juvenile plutonic pattern in the Eastern Dharwar craton. Juvenile crust is shown in medium and light grey. Stretching directions are shown by arrows and circles. Longitudinal constrictional stretching compensates lateral shortening, volume increase due to juvenile magmatic accretion, and vertical stretching of greenstones in order not to modify crustal thickness. Conjugate strike-slip shear zones are omitted. S, Sira type; C, Closepet type; K, Krishnagiri type. 
approximated to bulk horizontal plane strain deformation of an entire crustal province responding to shortening, gravity and magmatic accretion by lateral flow. Finite plane strain deformation is a combination of horizontal tectonic pure shear and volumetric strain due to juvenile magmatic accretion.

[43] Horizontal constrictional flow (and vertical flattening) acted to maintain the plane strain condition imposed by the low strength and buoyancy of the partially molten crust. These two processes balanced heterogeneities generated by shortening and/or diapirism (mainly in the thin upper crust) and absorbed the juvenile magmatic volumetric component of strain. Within that framework, the transtensional component of constrictional flow was efficient at making room for juvenile plutons in an overall context of shortening.

[44] The strain field of the Eastern Dharwar craton is that of a wide hot orogen [Cruden et al., 2006]. It is consistent with mechanical simulations on shortening of weak lithospheres [Cagnard et al., 2006a; Cruden et al., 2006; Rey and Houseman, 2006; Duclaux et al., 2007]. These models predict that the whole lithosphere can flow laterally in response to shortening. There is a great variability, both in space and time, in the strain symmetries within model hot orogens [Cruden et al., 2006; Duclaux et al., 2007]. This is in agreement with the strain patterns documented in the Eastern Dharwar craton between 2.56 and $2.51 \mathrm{Ga}$, which include horizontal flattening, horizontal plane strain and horizontal constriction normal to the shortening direction.

[45] Lateral lithospheric flow requires specific free boundary conditions to proceed. Lateral extrusion is preferred here to free boundary gravitational collapse [Rey et al., 2001] because the considered segment of lithosphere was probably not thickened enough to collapse.

\section{Conclusion}

[46] Penetrative crustal fabrics play a first-order role in accommodating deformation and mass balance of a weak continental lithosphere submitted to shortening, as opposed to structurally controlled deformation (i.e., strain localization along crustal or lithospheric-scale shear zones). The example of the Eastern Dharwar craton provides a deformation mode by which an extremely weak lithosphere responds to convergence by developing bulk, homogeneous, horizontal plane strain on a crustal scale, resulting from both gravity- and tectonic-driven horizontal flow perpendicular to the direction of shortening. Orogen-parallel, horizontal constrictional flow acted to maintain a stable crustal thickness through juvenile magmatic accretion and tectonic thickening, resulting in horizontal finite plane strain. Such an orogen-scale deformation mode would explain slow and nearly isobaric cooling of HT-LP highgrade terrains. The transtensional component of constrictional flow was instrumental in assisting growth of large juvenile felsic intrusions during shortening and is proposed to provide a resolution of the batholithic room problem in a particularly softened crust undergoing convergence.

[47] Horizontal, plane strain deformation is an endmember orogen development mode in an extremely weakened lithosphere submitted to pervasive juvenile magmatic accretion and partial melting. Under lower thermal regimes, the ability of continental orogens to thicken through time led to the record of Barrovian metamorphism, nonisobaric retrograde P-T-t paths, and, ultimately, late-orogenic collapse.

[48] Acknowledgments. Fieldwork was funded by the Indo-French Centre for the Promotion of Advanced Research (IFCPAR project 2307-1). Thanks are due to J.-J. Peucat, B. Mahabaleswar, T. R. K. Chetty, and P. Pitra for discussions, support, and/or participation in part of the fieldwork. We are grateful to P. Rey, B. Tikoff, A. Cruden, and D. Gapais for stimulating comments, suggestions, and criticisms on successive drafts of the manuscript.

\section{References}

Bohlen, S. R. (1991), On the formation of granulites, J. Metamorph. Geol., 9, 223-229.

Bouhallier, H. (1995), Evolution structurale et metamorphique de la croute continentale archeenne (Craton de Dharwar Inde du Sud), Mem. Geosci. Rennes, 60, 1-214.

Bouhallier, H., D. Chardon, and P. Choukroune (1995), Strain patterns in Archaean dome-and-basin structures: The Dharwar craton (Karnataka South India), Earth Planet. Sci. Lett., 135, 57-75.

Brun, J.-P. (1983), Isotropic points and lines in strain fields, J. Struct. Geol., 5, 321-327.

Brun, J.-P., and J. Pons (1981), Strain patterns of pluton emplacement in a crust undergoing non-coaxial deformation, Sierra Morena, Southern Spain, J. Struct. Geol., 3, 219-229.

Bühl, D., B. Grauert, and M. Raith (1983), U-Pb zircon dating of Archean rocks from the south Indian craton: Results from the amphibolite to granulite facies transition zone at Kabbal quarry, Southern Karanataka, Fortschr. Mineral., 61, 43-45.

Cagnard, F., N. Durrieu, D. Gapais, J.-P. Brun, and C. Ehlers (2006a), Crustal thickening and lateral flow during compression of hot lithospheres, with particular reference to Precambrian times, Terra Nova, 18, 72-78

Cagnard, F., J.-P. Brun, and D. Gapais (2006b), Modes of thickening of analogue weak lithospheres, Tectonophysics, 421, 145-160.

Chadwick, B., V. N. Vasudev, and N. Ahmed (1996), The Sandur schist belt and its adjacent plutonic rocks: Implications for Late Archean crustal evolution in Karnataka, J. Geol. Soc. India, 47, 37-57.

Chadwick, B., V. N. Vasudev, and G. V. Hedge (2000), The Dharwar craton, southern India, interpreted as the result of Late Archaean oblique convergence, Precambrian Res., 99, 91-101.

Chardon, D., J.-J. Peucat, M. Jayananda, P. Choukroune, and C. M. Fanning (2002), Archean granite-greenstone tectonics at Kolar (South India): Interplay of diapirism and bulk inhomogeneous contraction during magmatic juvenile accretion, Tectonics, 21(3), 1016, doi:10.1029 2001 TC901032.

Choukroune, P., H. Bouhallier, N. T. Arndt (1995), Soft lithosphere during periods of Archean crustal growth or crustal reworking, in Early Precambrian Processes, edited by M. P. Coward and A. C. Ries, Geol. Soc. Spec. Publ., 95, 67-86.
Collins, W. J. (2002), Hot orogens, tectonic switching, and creation of continental crust, Geology, 30, $535-538$.

Cruden, A. R., M. H. B. Nasseri, R. Pysklywec (2006), Surface topography and internal strain variation in wide hot orogens from three-dimensional analogue and two-dimensional numerical vice models, in Analogue and Numerical Modelling of Crustal-Scale Processes, edited by S. J. H. Buiter and G. Schreurs, Geol. Soc. Spec. Publ., 253, 79-104.

de Saint Blanquat, M., B. Tikoff, C. Teyssier, and J.-L. Vigneresse (1998), Transpressional kinematics and magmatic arcs, in Continental Transpressional and Transtensional Tectonics, edited by R. E. Holdsworth, R. A. Strachan, and J. F. Dewey, Geol. Soc. Spec. Publ., 135, 327-340.

Dewey, J. F., R. E. Holdsworth, R. A. Strachan (1998), Transpression and transtension zones, in Continental Transpressional and Transtensional Tectonics, edited by R. E. Holdsworth, R. A. Strachan, and J. F. Dewey, Geol. Soc. Spec. Publ., 135, 1-14.

Dirks, P. H. G. M., J. S. Zhang, and C. W. Passchier (1997), Exhumation of high-pressure granulites and the role of lower crustal advection in the North 
China Craton near Datong, J. Struct. Geol., 19, $1343-1358$.

Drury, S. A., and R. W. Holt (1980), The tectonic framework of the South Indian craton: A reconnaissance involving LANDSAT imagery, Tectonophysics, $65,1-15$

Drury, S. A., N. B. Harris, R. W. Holt, G. J. ReevesSmith, and R. T. Wightman (1984), Precambrian tectonics and crustal evolution in South India, J. Geol., 92, 3-20.

Duclaux, G., P. Rey, S. Guillot, and R.-P. Ménot (2007), Orogen-parallel flow during continental convergence: Numerical experiments and Archean field examples, Geology, 35, 715-718

Friend, C. R. L., and A. P. Nutman (1991), SHRIMP $\mathrm{U}-\mathrm{Pb}$ geochronology of the Closepet granite and Peninsular gneisses, Karnataka, South of India, J. Geol. Soc. India, 38, 357-368.

Gapais, D. (1989), Shear structures within deformed granites: Thermal and mechanical indicators, Geology, 17, 1144-1147.

Hansen, E. C., R. C. Newton, and S. Janardhan (1984a), Pressures, temperatures and metamorphic fluids across an unbroken amphibolite facies to granulite facies transition in southern Karnataka, India, in Archaean Geochemistry, edited by A. Kröner and A. M. Goodwin, pp. 160-181, Springer-Verlag, Berlin.

Hansen, E. C., R. C. Newton, and S. Janardhan (1984b), Fluid inclusions in rocks from the amphibolite-facies gneiss to charnockite progression in southern Karnataka, India: Direct evidence concerning the fluids of granulite metamorphism, J. Metamorph. Geol., 2, 249-264.

Hansen, E. C., R. C. Newton, A. S. Janardhan, and S. Lindenberg (1995), Differentiation of Late Archean crust in the Eastern Dharwar craton, Krishnagiri-Salem area, South India, J. Geol., 103, $629-651$.

Hutton, D. H. W. (1988), Granite emplacement mechanisms and tectonic controls: Inferences from deformation studies, Trans. R. Soc. Edinburgh Earth Sci., 79, 245-255.

Janardhan, A. S., R. C. Newton, and E. C. Hansen (1982), The transformation of amphibolite facies gneisses to charnockite in southern Karnataka and Tamil Nadu, Contrib. Mineral. Petrol., 79, 139149

Jayananda, M., and B. Mahabaleswar (1991), Relationship between shear zones and igneous activity: The Closepet granite of Southern India, Proc. Indian Acad. Sci., Earth Planet. Sci., 100, 31-36.

Jayananda, M., H. Martin, J.-J. Peucat, and B. Mahabaleswar (1995), Late archaean crust-mantle interactions: Geochemistry of LREE-enriched mantle derived magmas, Example of the Closepet batholith, Southern India, Contrib. Mineral. Petrol., 119, 314-329.

Jayananda, M., J.-F. Moyen, H. Martin, J.-J. Peucat, B. Auvray, and B. Mahabaleswar (2000), Late Archaean $(2550-2520 \mathrm{Ma})$ juvenile magmatism in the Eastern Dharwar craton, southern India: Constraints from geochronology, $\mathrm{Nd}-\mathrm{Sr}$ isotopes and whole rock geochemistry, Precambrian Res., 99 $225-254$.

Mahabaleswar, B., and J. J. Peucat (1988), 2.9 b.y. Rb$\mathrm{Sr}$ age of the granulite facies rocks of SatnurHalagur and Sivasamudram areas, Karnataka, South India, J. Geol. Soc. India, 32, 461-467.

Mahabaleswar, B., M. Jayananda, J.-J. Peucat, and N. Shadakshara Swamy (1995), Archaean highgrade gneiss complex from Satnur-Halagur-Sivasamudram areas, Karnataka, southern India: Petrogenesis and crustal evolution, J. Geol. Soc. India , 45, 33-49.

Martelat, J.-E., J.-M. Lardeaux, C. Nicollet, and R. Rakotondrazafy (2000), Strain pattern and late Precambrian deformation history in Southern Madagascar, Precambrian Res., 102, 1-20.

Matin, A. (2006), Structural anatomy of the Kushtagi schist belt, Dharwar craton, south India: An example of Archaean transpression, Precambrian Res. $147,28-40$.

Mojzis, S. J., T. C. Devaraju, and R. C. Newton (2003), Ion microprobe $\mathrm{U}-\mathrm{Pb}$ age determinations on zircon from the late Archean granulite facies transition zone of southern India, J. Geol., 111, 407-425.

Moyen, J.-F., H. Martin, and M. Jayananda (2001), Multi-element geochemical modelling of crustmantle interactions during late-Archaean crusta growth: The Closepet granite (South India), Pre cambrian Res., 112, 87-105.

Moyen, J.-F., A. Martin, M. Jayananda, and B. Auvray (2003), Late Archaean granites: A typology based on the Dharwar craton (India), Precambrian Res. 127, $102-123$.

Moyen, J.-F., A. Nédélec, H. Martin, and M. Jayananda (2003), Syntectonic granite emplacement at different structural levels: The Closepet granite, South India, J. Struct. Geol., 25, 611-631.

Mukhopadhyay, D., and A. Matin (1993), The structural anatomy of the Sandur schist belt: A greenstone belt in the Dharwar craton of south India, J. Struct Geol., 15, 309-322.

Myers, J. S. (1976), Granitoid sheets, thrusting, and Archean crustal thickening in West Greenland, Geology, 5, 265-268

Newton, R. C. (1990a), Fluids and shear zones in the deep crust, Tectonophysics, 182, 21-37.

Newton, R. C. (1990b), The late Archean high-grade terrain of South India and the deep structure of the Dharwar craton, in Exposed Cross-Sections of the Continental Crust, edited by M. H. Salisbury and D. M. Fountain, pp. 305-326, Kluwer Acad. Amsterdam.

Park, R. G. (1981), Origin of horizontal structure in high-grade Archean terrains, Spec. Publ. Geol. Soc. Aust., 7, 481-490.

Peucat, J. J., B. Mahabaleswar, and M. Jayananda (1993), Age of younger tonalitic magmatism and granulitic metamorphism in the South Indian transition zone (Krishnagiri area): Comparison with older Peninsular gneisses from the Gorur-Hassan area, J. Metamorph. Geol., 11, 879-888.

Pichamuthu, C. S. (1960), Charnockite in the making, Nature, 188, 135-136.

Raase, P., M. Raith, D. Ackermand, and R. K. La (1986), Progressive metamorphism of mafic rocks from greenschist to granulite facies in the Dharwar Craton of south India, J. Geol., 94, 261-282.

Raith, M., P. Raase, D. Ackermand, and R. K. Lal (1983), Regional geothermobarometry in the granulite facies terrane of South India, Trans. R. Soc. Edinburgh Earth Sci., 73, 221-244.

Rey, P., and G. Houseman (2006), Lithospheric scale gravitational flow: The impact of body forces on orogenic processes from Archaean to Phanerozoic, in Analogue and Numerical Modelling of CrustalScale Processes, edited by S. J. H. Buiter and G. Schreurs, Geol. Soc. Spec. Publ., 253, 153-167.

Rey, P., O. Vanderhaeghe, and C. Teyssier (2001), Gravitational collapse of the continental crust: Definition, regimes and modes, Tectonophysics, 342 , $435-449$.

Sandiford, M. (1989), Horizontal structures in granulite terrains: A record of mountain building or mountain collapse?, Geology, 17, 449-452.

Shackleton, R. (1993), Tectonics of the lower crust: A view from the Usambara Mountains, NE Tanzania, J. Struct. Geol., 15, 663-671.

Sugavanam, E. B. (1984), Geological and structura map of parts of Kollegal Taluk, Mysore district, Karnataka, Geol. Surv. of India, Bangalore.

Suryanarayana, K. V. (1961), The Closepet granite and associated rocks (part I), Indian Mineral., 1, 86100

Suryanarayana, K. V. (1964), The Closepet granite and associated rocks (part II): Fabric of the Closepet granites, Indian Mineral., 5, 60-68.

Tikoff, B., M. de Saint Blanquat, and C. Teyssier (1999), Translation and the resolution of the pluton space problem, J. Struct. Geol., 21, 1109-1117.

Watterson, J. (1968), Homogeneous deformation of the gneisses of Vesterland, South-West Greenland, Grönlands Geol. Unders., 175, 1-73.

Wells, P. R. A. (1981), Accretion of continental crust: Thermal and geochemical consequences, Philos. Trans. R. Soc. London, Ser. A, 301, 347-357.

Williams, P. F., and D. Jiang (2005), An investigation of lower crustal deformation: Evidence for channel flow and its implications for tectonics and structural studies, J. Struct. Geol., 27, 1486-1504.

D. Chardon, Laboratoire des Mécanismes et Transferts en Géologie, Observatoire Midi-Pyrénées, Université Paul Sabatier, 14 avenue Edouard Belin, F-31400 Toulouse, France. (chardon@lmtg.obs-mip.fr) M. Jayananda, Department of Geology, Bangalore University, Bangalores 560 056, India. (mjayananda@ rediffmail.com) 